\title{
Comparative Study of Physico-Chemical Properties of Sediments from Two Sectors Close to Bandama in Northern Côte D'Ivoire (Sinematiali and Niakaramadougou)
}

\author{
Gnosseith Huberson Claver N'doufou ${ }^{*}$, Krogba Yves Nangah1, Koffi Hypolithe Kouadio² \\ ${ }^{1}$ Department of Geosciences, University Peleforo Gon Coulibaly, Korhogo, Côte d'Ivoire \\ ${ }^{2}$ UFR Agroforestry, Jean Lorougnon Guédé University, Daloa, Côte D’Ivoire \\ Email: ^gnosseith3@gmail.com
}

How to cite this paper: N'doufou, G. H. C., Nangah, K. Y., \& Kouadio, K. H. (2022). Comparative Study of Physico-Chemical Properties of Sediments from Two Sectors Close to Bandama in Northern Côte D'Ivoire (Sinematiali and Niakaramadougou). Journal of Geoscience and Environment Protection, 10, 33-46.

https://doi.org/10.4236/gep.2022.102003

Received: June 24, 2021

Accepted: February 11, 2022

Published: February 14, 2022

Copyright $\odot 2022$ by author(s) and Scientific Research Publishing Inc. This work is licensed under the Creative Commons Attribution International License (CC BY 4.0).

http://creativecommons.org/licenses/by/4.0/

\section{(c) (i) Open Access}

\begin{abstract}
This study aims to show the impact of successive floods on the spatial variation of the physico-chemical properties of sediments along the Bandama River in the localities of Sinématiali and Niakaramadougou because of their importance in the functioning of this ecosystem. Several samples were taken from both stations based on flood recurrence areas. The particle size analysis was done using the Robinson's Pipette method. Traditional methods of sediment analysis have been used to measure organic carbon (O.C.), nitrogen $(\mathrm{N})$, and other chemical properties including $\mathrm{pH}$, organic matter $(\mathrm{MO})$, and $\mathrm{C} / \mathrm{N}$ ratio. Statistical analyzes were carried out to assess the differences between the physico-chemical parameters of the different sampling zones. In the area of niakamadougou, the lower values in MO were recorded in areas subject to more frequent flooding, thus close to the watercourse. In the Sinématiali area, lower M.O. values were recorded in sediments far from the stream. Total organic matter levels are higher in surface sediments with the lowest proportions of clay. The results show that the physico-chemical properties of the sediments vary at the level of the vertical distribution and according to their spatial distribution. Successive floods have a direct effect on the dynamics of the physico-chemical properties of sediments along the shore.
\end{abstract}

\section{Keywords}

Organic Matter, Granulometry, Successive Flood, Physico-Chemical Properties of Sediment 


\section{Introduction}

The number of studies on the effects of climate change on the environment has increased steadily over the past decades, and these changes have a direct impact on river flow patterns and play a decisive role in stabilizing riparian ecosystems (Leroy Poff, 2002; Schipper et al., 2010). There is an increase in precipitation, an increase in flow levels, an increase in flooding, and a vertical increase in alluvial plains in active sedimentary areas affected by periodic floods (Saint-Laurent \& Lavoie, 2009).

It is important to quantify the impact of climate change on the river environment in order to better understand how these environments will evolve in the coming decades. Riparian ecosystems vary widely depending on river dynamics (Boyer et al., 2010). The constant input of sediment carried by successive floods has an impact on the physico-chemical properties of the sediment. The latter can vary enormously in vertical distribution and spatial distribution, which are influenced by various hydrological processes (Clinton et al., 2003; Watkins et al., 2010).

Successive or periodic river floods cause changes in riparian ecosystems (SaintLaurent, 2007). There should be marked differences between sediments located close to the shore, thus frequently flooded, and areas further away.

This study will attempt to highlight the impact of recurrent flooding on the physico-chemical properties of sediment in two areas along the Bandama River. This will include understanding the distribution of physico-chemical parameters of distant sediments from the watercourse and comparing them with those of the nearby environment to highlight the impact of floods on the river environment.

The particles that make up the sediment are composed of organic and inorganic compounds (Schneider, 2001). The chemical composition of sediment is specific to its environment and to the emitting sources near the deposition area. However, the particles that make up the sediment will also undergo and/or induce bio-geochemical transformations that will lead first to changes in physico-chemical composition and then to the formation of sedimentary rock (Zhou, 2009). These processes are governed primarily by the mineralization of the MO in the sedimentary column. After the MO is buried in the sediment, it will undergo progressive degradation through oxido-reduction reactions controlled primarily by bacterial activity (Billon, 2001). Surface sediment is one of the most important and dynamic reservoirs of organic matter in terms of stock (Cyril, 2003). Each year, nearly $0.4 \mathrm{Gt}$ of terrestrial organic carbon is transported to coastal environments (Siegenthaler \& Sarmiento, 1993). The study of the physico-chemical properties of sediments, particularly sedimentary organic matter in today's environments, could serve as a basis for paleoclimatic, paleoenvironmental interpretations (Meyers \& Lallier-Vergès, 1999). Sedimentary organic matter consisting primarily of organic carbon and nitrogen has an impact on the sustainable functioning of ecosystems (Woomer et al., 1998). 
The main objective of this study is to assess the spatial distribution of the physico-chemical properties of sediments along the Bandama River in the localities of Niakaramadou and Sinématiali following the floods recorded in recent years. Previous work shows little information on the distribution of these physicochemical parameters in sediments along the banks of the Bandama River. As a result, this study will attempt to highlight the impact of recurrent flooding on the organic matter of the sediments in this area. This will assess the levels of organic matter in sediments far from the watercourse and compare them with those in the nearby environment to highlight the impact of floods on the river environment. To carry out this work, a multidisciplinary approach was taken. It is based in particular on sedimentological and soil studies.

\section{Material and Methods}

\subsection{Location and Sampling}

Four sampling points along the shore were predefined and were sampled from surface sediments at a depth of 10 to $150 \mathrm{~cm}$ Figure 1 . The various analyzes carried out in this study were carried out on the fine fraction $(<2 \mathrm{~mm})$, which we separated at the laboratory a few weeks after sampling.

These samples were analyzed to determine:

- The particle size (sandy, clay and lemon fraction), $\mathrm{pH}$, total organic carbon, total nitrogen and organic matter.

- The analysis of each of these parameters involved specific methods as described below.

\subsection{Physico-Chemical Characterization of Sediment}

\subsubsection{Physical Parameters of Sediments}

\section{- Granulometry and Texture}

It was determined by Robinson's Pipette method (AFNOR, 1987).

The application of this analysis allowed:

- To know the substances (MO and nitrogen) associated with the particle size fractions contained in the sediment. It is used to determine whether they are located in the fine, medium or coarse fractions;

- To reconstitute the conditions for transport and deposition of particles.

We used the triangular diagram of fine soils proposed by Shepard (1954). This type of diagram is particularly suitable for sediments because sediments can then be characterized according to the respective content of these three particle size fractions (clays, silt and sand) (Bonnet, 2000; Mamadou, 2018).

\subsubsection{Chemical Sediment Parameters}

On the same samples we also determined $\mathrm{CO}, \mathrm{MO}$, nitrogen and $\mathrm{PH}$ levels.

Water $\mathrm{pH}$ was determined by measuring $\mathrm{H}_{3} \mathrm{O}^{+}$ion activity using a $\mathrm{pH}$ meter (Rofes, 1980).

Organic carbon of sediments is determined by the Anne method (Aubert, 1978). The carbon of the organic matter is oxidized by potassium bichromate in 


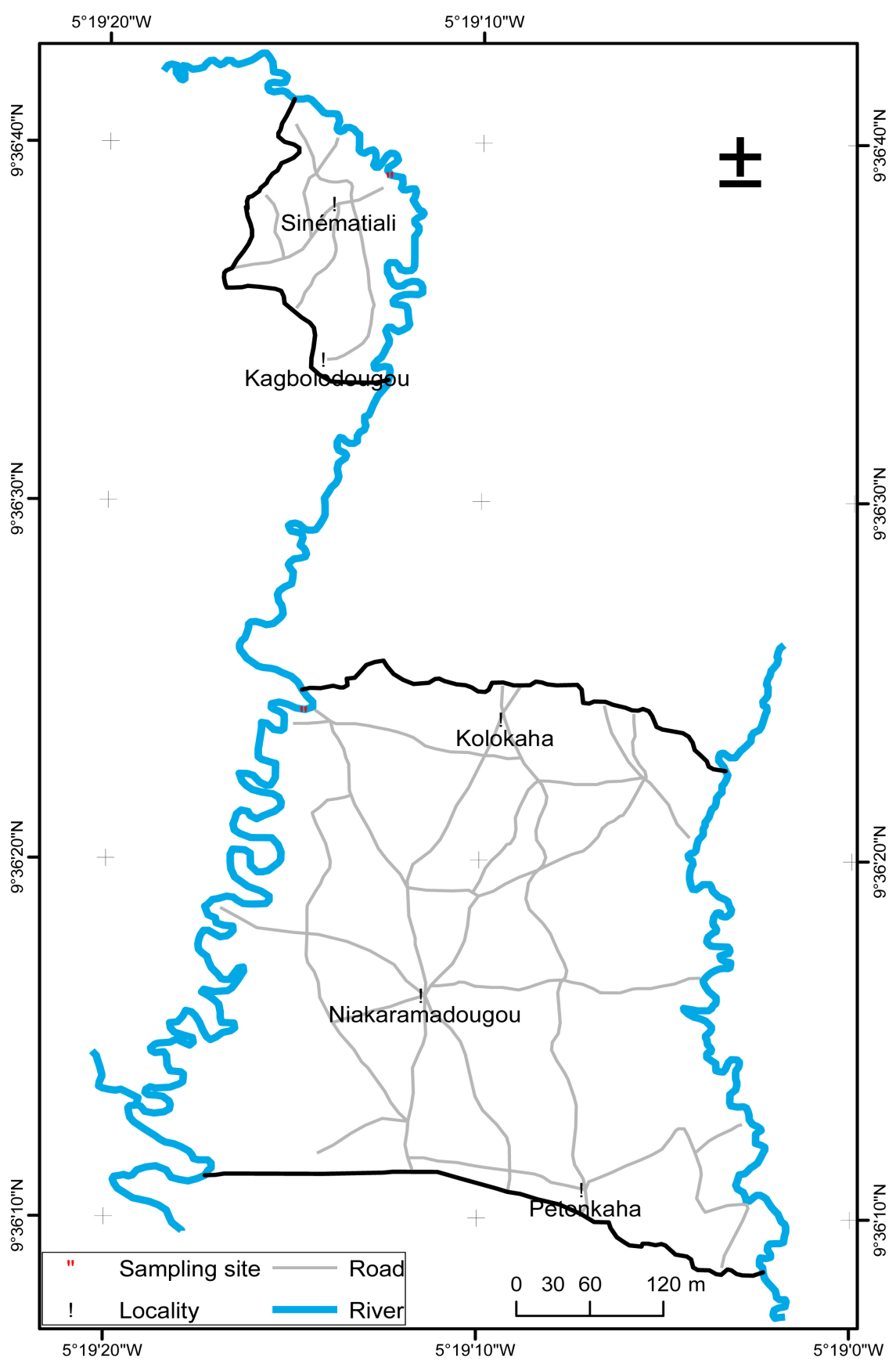

Figure 1. Location map.

sulfuric medium. The assessment of the organic matter content was made by quantifying its major constituent element, organic carbon, which represents almost 50\% of this element (Thurman \& Malcolm, 1981). The content of the MO was assessed on the basis of the following conventional relationship: $\mathrm{MO}=\mathrm{C} \times$ 1.72 (Baize, 2000). Nitrogen in sediments was determined by the Kjeldahl method (Rofes, 1980). The principle of this method is to transform the nitrogen of organic compounds from a finely crushed sediment sample into ammoniacal nitrogen under the action of concentrated sulfuric acid, which, when boiled, be- 
haves as an oxidant. Organic substances are decomposed: carbon comes out as carbon dioxide, hydrogen gives water, and nitrogen is transformed into ammonia nitrogen. The latter is fixed immediately by sulfuric acid in the form of ammonium sulfate. The $\mathrm{C} / \mathrm{N}$ ratio is an indicator of sediment biological activity that provides information on the degree of organic matter evolution, biological activity, mineralization. The smaller the biological activity, the more difficulties encountered in mineralization. This reflects conditions of anaerobic, excessive acidity. The study of the $\mathrm{C} / \mathrm{N}$ report is an approach to the problem of the origin, nature and evolution of organic matter (Delmas, 1980).

\subsubsection{Statistical Analysis}

For data analysis, we used variance analysis of different variables using SAS 9.4 software. The significance test is Fischer's distribution or "F test" at the $5 \%$ probability threshold. Correlation tests (Pearson) were also performed between variables (MO, pH, C.O., N, texture). These tests allowed comparisons of different parameters according to the horizontal gradient (channel distance) and vertical (depth). We converted the units of $\%$ to $\mathrm{g} \cdot \mathrm{kg}^{-1}$ (international unit) for carbon, nitrogen and organic matter $(\mathrm{MO})$.

\section{Results}

\subsection{Granulometry According to Sectors, Positions (Near or Far from the Watercourse) and Layers}

Analysis of variance showed a significant difference between clay and sand between localities. For clay, Sinématialie obtained the highest quantity with $22.18 \%$. Niakaraougoumad had the highest quantity of sand at $50.95 \%$. For silt and the proportion of physical soil elements the two localities had similar amounts (Table 1). Analysis of variance showed a significant difference between the positions (close to the watercourse and distant from the watercourse) for clay. The position near the water yard obtained the highest amount of clay at $21.71 \%$. For silt, sand and the proportion of physical elements, no significant differences were observed between the two positions (Table 1). Analysis of variance showed a significant difference between clay layers. Layer C2 obtained the highest quantity $19.63 \%$ and layer $\mathrm{C} 1$ the lowest quantity $16.88 \%$. For the other variables, no significant differences were found between layers "Table 1 ".

\subsection{Assessment of Chemical Characteristics by Sectors, Positions and Layers}

Analysis of variance showed a significant difference in $\mathrm{pH}$ between localities. Niakaramadougou had the highest value at 6.27. For carbon, nitrogen, $\mathrm{C} / \mathrm{N}$, and organic matter (MO), both localities had similar amounts statistically (Table 2).

Analysis of variance did not show a significant difference between the positions (near the watercourse and away from the watercourse) for all variables (Table 2). 
Table 1. Comparison of physical characteristics of sediment between layers, positions and sectors.

\begin{tabular}{ccccc}
\hline Variable & \% Clay & \% in Limon & \% Sand & \% Physical Elements \\
\hline Locality & & & & \\
Niakara & $16.00 \mathrm{~b}$ & $30.81 \mathrm{a}$ & $50.95 \mathrm{a}$ & $97.76 \mathrm{a}$ \\
Sinématialie & $22.18 \mathrm{a}$ & $34.27 \mathrm{a}$ & $41.99 \mathrm{~b}$ & $98.45 \mathrm{a}$ \\
Pr $>$ F & 0.0004 & 0.2820 & 0.0308 & 0.3055 \\
Position & & & & \\
Near the river & $21.71 \mathrm{a}$ & $33.16 \mathrm{a}$ & $43.12 \mathrm{a}$ & $97.99 \mathrm{a}$ \\
Far from the river & $16.48 \mathrm{~b}$ & $31.92 \mathrm{a}$ & $49.83 \mathrm{a}$ & $98.22 \mathrm{a}$ \\
Pr > F & 0.0011 & 0.6890 & 0.0860 & 0.7246 \\
Layer & & & & $97.17 \mathbf{a}$ \\
C1 & $16.88 \mathrm{~b}$ & $36.01 \mathrm{a}$ & $44.28 \mathrm{a}$ & $98.48 \mathrm{a}$ \\
C2 & $20.78 \mathrm{a}$ & $32.04 \mathrm{a}$ & $45.66 \mathrm{a}$ & $98.67 \mathrm{a}$ \\
C3 & $19.63 \mathrm{ab}$ & $29.56 \mathrm{a}$ & $49.48 \mathrm{a}$ & 0.1669 \\
Pr > F & 0.043 & 0.266 & 0.4723 & 98.106 \\
Average & 19.09 & 32.54 & 46.47 & 3.67 \\
C.V. (p.c.) & 8.69 & 12.83 & 11.54 &
\end{tabular}

Means followed by the same letters in a column are not significantly different from the 5 p.c. threshold.

Table 2. Comparison of sediment chemical parameters between layers, positions and sectors.

\begin{tabular}{|c|c|c|c|c|c|}
\hline Variable & $\begin{array}{l}\text { Carbon } \\
\left(\mathrm{g} \cdot \mathrm{kg}^{-1}\right)\end{array}$ & $\begin{array}{c}\text { Nitrogen } \\
\left(\mathrm{g} \cdot \mathrm{kg}^{-1}\right)\end{array}$ & $\mathrm{C} / \mathrm{N}$ & $\begin{array}{c}\mathrm{OM} \\
\left(\mathrm{g} \cdot \mathrm{kg}^{-1}\right)\end{array}$ & $\mathrm{pH}$ \\
\hline \multicolumn{6}{|l|}{ Locality } \\
\hline Niakara & $11.84 \mathrm{a}$ & $0.66 \mathrm{a}$ & $19.92 \mathbf{a}$ & $20,42 \mathbf{a}$ & $6.27 \mathrm{a}$ \\
\hline Sinématiali & $11.38 \mathrm{a}$ & $0.60 \mathrm{a}$ & 18.47 a & 19.61 a & $5.76 \mathrm{~b}$ \\
\hline $\operatorname{Pr}>F$ & 0.9070 & 0.8969 & 0.5929 & 0.9105 & 0.0096 \\
\hline \multicolumn{6}{|l|}{ Position } \\
\hline Near the river & 10,97 a & $0,59 \mathrm{a}$ & 18.79 a & 18,91 a & $5.87 \mathrm{a}$ \\
\hline Far from the river & $12.25 \mathrm{a}$ & $0.67 \mathrm{a}$ & $19.60 \mathrm{a}$ & $21.12 \mathrm{a}$ & $6.15 \mathrm{a}$ \\
\hline $\operatorname{Pr}>F$ & 0.9695 & 0.9215 & 0.7638 & 0.9653 & 0.0992 \\
\hline \multicolumn{6}{|l|}{ Layer } \\
\hline $\mathrm{C} 1$ & $21.45 \mathrm{a}$ & $1.15 \mathrm{a}$ & 19.71 a & 36.98 a & $6.12 \mathrm{a}$ \\
\hline $\mathrm{C} 2$ & $9.38 \mathrm{~b}$ & $0.48 \mathrm{~b}$ & $21.12 \mathrm{a}$ & $16.18 \mathrm{~b}$ & $5.85 \mathrm{a}$ \\
\hline C3 & $3.99 \mathrm{c}$ & $0.26 \mathrm{~b}$ & $16.75 \mathrm{a}$ & $6.88 c$ & $6.06 \mathrm{a}$ \\
\hline $\operatorname{Pr}>F$ & 0.0008 & 0.0026 & 0.4161 & 0.0008 & 0.3654 \\
\hline Average & 11.61 & 0.63 & 19.19 & 20.01 & 6.01 \\
\hline C.V. (p.c.) & 26.07 & 28.16 & 33.17 & 26.23 & 6.180 \\
\hline
\end{tabular}

Means followed by the same letters in a column are not significantly different from the 5 p.c. threshold. 
Analysis of variance showed significant differences between the layers for carbon, nitrogen and organic matter (MO). For carbon, layer $\mathrm{C} 1$ had the highest quantity $36.98 \mathrm{~kg}^{-1}$ and layer C3 the lowest quantity $6.88 \mathrm{~kg}^{-1}$. Similarly, for organic matter layer $\mathrm{C} 1$ had the highest quantity $21.45 \mathrm{~g} \cdot \mathrm{kg}^{-1}$ and layer $\mathrm{C} 3$ the lowest quantity $3.99 \mathrm{~g} \cdot \mathrm{kg}^{-1}$. N, layer $\mathrm{C} 1$ had the highest value $1.15 \mathrm{~g} \cdot \mathrm{kg}^{-1}$, the other two layers had identical values Table 2.

\subsection{Pearson Correlation Test}

The Pearson correlation analysis showed a correlation between CEC and some grain size fraction variables (clay and fine silt). The CEC was strongly correlated with clay with a positive correlation coefficient of 0.73 . The correlation coefficient between the CEC and the fine silt was positive but average (0.56). Negative correlations were found between the CEC and coarse and fine sands with correlation coefficients of -0.75 and -0.89 , respectively. Correlations between the different particle size fractions were shown. This is clay that was negatively correlated with coarse and fine sands with -0.83 and -0.77 respectively as the correlation coefficient. Fine silt and coarse sand were positively correlated with coarse silt (0.62) and fine sand (0.68), respectively. However, fine silt was negatively correlated with fine sand $(-0.74)$ "Table 3 ".

\section{Discussion}

\subsection{Spatio-Temporal Variation of Physico-Chemical Properties of Sediments}

The results show relatively low levels of organic matter in the study area. These relatively low levels appear to be characteristic of this medium. They are the response of the disturbances linked to successive floods. The accumulation of organic matter is difficult due to the phenomenon of floods and decouples, which is an obstacle preventing the formation of a dense vegetation cover. Successive

Table 3. Comparative study of the correlation between the analysis data of the two sectors (Sinematiali and Niakaramadougou).

\begin{tabular}{|c|c|c|c|c|c|c|c|c|c|}
\hline & $\mathrm{pH}_{\text {eau }}$ & $\begin{array}{c}\text { Organic } \\
\text { carbon (\%) }\end{array}$ & CEC & Clay (\%) & $\begin{array}{c}\text { Fine } \\
\text { Limon (\%) }\end{array}$ & $\begin{array}{c}\text { Coarse } \\
\text { Limon (\%) }\end{array}$ & $\begin{array}{c}\text { Coarse } \\
\text { sand }(\%)\end{array}$ & $\begin{array}{c}\text { Fine sand } \\
\text { fin (\%) }\end{array}$ & $\begin{array}{l}\mathrm{OM} \\
(\%)\end{array}$ \\
\hline $\mathrm{pH}_{\text {eau }}$ & 1.00 & & & & & & & & \\
\hline Organic carbon (\%) & 0.04 & 1.00 & & & & & & & \\
\hline CEC & -0.31 & 0.40 & 1.00 & & & & & & \\
\hline Clay (\%) & -0.50 & -0.26 & 0.73 & 1.00 & & & & & \\
\hline Fine Limon (\%) & -0.43 & 0.42 & 0.56 & 0.27 & 1.00 & & & & \\
\hline Coarse Limon (\%) & -0.18 & 0.28 & -0.02 & -0.33 & 0.62 & 1.00 & & & \\
\hline Coarse sand (\%) & 0.54 & -0.06 & -0.75 & -0.83 & -0.26 & 0.18 & 1.00 & & \\
\hline Fine sand (\%) & 0.52 & -0.21 & -0.89 & -0.77 & -0.74 & -0.15 & 0.68 & 1.00 & \\
\hline $\mathrm{OM}(\%)$ & 0.04 & 1.00 & 0.40 & -0.26 & 0.42 & 0.28 & -0.06 & -0.21 & 1.00 \\
\hline
\end{tabular}

Bold values show a strong correlation between the two variables. 
or periodic river floods cause changes in riparian ecosystems (Saint-Laurent, 2007). These results are identical to the work done by (Daniel et al., 1970), which states that alluvial soils are also characterized by low concentrations of organic matter in situ due to the absence or near-absence of surface litter.

The majority of samples analyzed in the study areas are sandy-lime textures with a higher proportion of clay (about 20\%) in the area closer to the stream. In contrast, in the area farther from the stream, this proportion of clay is about $10 \%$. This slight variability in the two areas is explained by hydromorphological conditions (erosion and sedimentation) that vary from one area to another. The rate of sedimentation is lower in the area far from the stream. For the area close to the channel, this significant presence of finer particles or clay could be explained by the deposition of fine river sediments suspended during the floods. In the remote area of the stream, this very small proportion of clay is due to the fact that during floods, water containing fine suspended sediment reaches this area very irregularly or very rarely. The textural variability is due to the diversity of movable deposits that make up the land outside the flood plains (Brunet \& Astin, 2000).

Depending on the origin of the sampling point, large particle size variations can be detected (Boulvain, 2011a). However, in some locations, the availability of sediment at source will influence the grain size distribution. If the only material available in the sedimentation basin is a material made up of fine particles, the transport agent will not be able to convey coarser particles than those available at source (Boulvain, 2011b). Results from Niakaramadougou show a lower level of MO in sediment, when approaching the channel. This low level of MO in the vicinity of the channel is due to the occasional floods and decues that favor the transport of certain elements (Lavoie et al., 2006). It is suggested that the erosion phases associated with floods and decays result in a rearrangement of the sediment. This oxidizes the various elements and thus rapidly re-mineralizes the MO, thus explaining the low levels of MO in the sediments. These results are consistent with Daniels (2003), which indicated that alluvial sediment is also characterized by low levels of organic matter in its natural environment due to the low presence or near-absence of litter. Low amounts of organic matter are associated with different hydroclimatic changes (Schilling et al., 2009). Higher concentrations of organic matter are found in areas further away $(5,10,20,30$ $\mathrm{m}$ ) from shore that are less prone to flooding, compared to areas directly subject to frequent flooding (Drouin et al., 2011). Also, the study of Cierjacks et al. (2010) shows that the concentration of organic matter in sediments increases significantly with the distance from the main channel. They have less disturbance from river bed overflows. In the Sinématiali area, lower M.O. values were recorded in sediments far from the stream. These results are not consistent with the work cited above. These results could be explained in two non-contradictory ways: first, the high rate of sedimentation prevents oxidative degradation of this material at the interface, where degradation processes are generally most active (Hartman et al., 1976). However, the organic matter that sedimentes, partly al- 
tered by its river transit, is particularly resistant to bacterial attacks (Bordovskiy, 1965). The organic matter content depends on alluvial sedimentation (Cierjacks et al., 2010); then the allochthonous organic matter carried by the stream (the river) and deposited near the stream not far from the banks could explain the higher levels of organic matter in areas near the stream. This reflects the diversity of sources of supply in this area. Organic matter deposited in an aquatic environment may have an Aboriginal origin and, to a more variable degree, an allochthonous origin (Ouertani et al., 2006). A significant fraction of this organic matter is degraded chemically and biologically in the water column. A more or less significant amount $(10 \%-60 \%)$ reaches the surface of the sediment (Kaplan \& Rittenberg, 1963) where it will be subjected to other chemical and biological transformations. A final fraction, the most stable, will be buried (Belin, 1992). Numerous studies have shown the different impacts of flooding in riparian environments (Nestler \& Long, 1997; Monirul et al., 2003; Saint-Laurent et al., 2011). The physico-chemical properties of sediments vary greatly depending on stream flow, sedimentary load, and the different recurrences and modes of flooding (Cierjacks et al., 2010). The frequency and duration of flooding has a real impact on the quality and quantity of sedimentation (Steiger et al., 2003; Zhang \& Mitsch, 2006). Numerous studies have shown the different impacts related to this river phenomenon (Nestler \& Long, 1997; Monirul et al., 2003; Pfister et al., 2004; Saint-Laurent \& Lavoie, 2009). Floods and declines can have beneficial or harmful effects on riparian ecosystems (Shields et al., 2000; Lavoie et al., 2006; Frazier \& Page, 2008; Drouin et al., 2011; Strom et al., 2011).

\subsection{Variation of Organic Matter Content by Particle Size Fractions}

The results show that the $\mathrm{CO}$ content is higher in the surface areas than in the depths with the highest proportions of clay. The vast majority of authors agree that clay and O.C. levels are positively correlated. According to Nadeu et al. (2010), the concentration of organic carbon in sediments is related to the abundance of different particle size fractions. There is a significant correlation between organic carbon and particle size distribution. The work of Krull et al. (2003), Jindaluang et al. (2013) show that a high concentration of organic carbon is often associated with a high proportion of clays in sediments. Indeed, the proportion of clay is an important factor for the stabilization of the O.C. in the soil because of the formation of the clay-humic complex and the physical protection it provides to the O.C. by binding inside the aggregates. In addition, the stability of aggregates caused by higher clay levels would reduce the risk of erosion, which can affect organic carbon reserves (Krull et al., 2003; Jindaluang et al., 2013). There are strong relationships between the mineralogical composition of sediments, including clay fraction and organic matter preservation (Keil et al., 1994). The concentration of organic carbon is higher in fine-matrix sediments than those with coarse matrix (Gretener \& Stromquist, 1987; Schilling et al., 2009; Cierjacks et al., 2010; Nadeu et al., 2010). However, several studies show that there may be significant variability in O.C. concentrations throughout the 
profile, particularly for riparian soils (Schilling et al., 2009; Su et al., 2006). This diversity of opinion makes categorical conclusions difficult.

\section{Conclusion}

We see a slight decrease in organic matter content when we get closer to the stream in the niakamadougou sector. Lower values were recorded in areas subject to more frequent flooding. In the Sinématiali area, lower M.O. values were recorded in sediments far from the stream. This difference is not significant. Across the study area, the MO content is generally higher in sediment from surfaces with the lowest proportions of clay. Organic carbon and nitrogen follow almost the same pattern as that of MO. Analysis of variance showed significant differences for carbon, nitrogen and organic matter (MO) at the layer level. The particle size of the sediments varies more or less according to the different alluvial zones studied. In Niakamadougou, analyzes generally revealed a sandy-clayey texture when close to the stream and a sandy-limonous texture when moving away from the stream. In Sinématiali, the results show that the sediments have a predominantly sandy-limonous to limono-clayey texture. The textural variability observed in the zones is due to the diversity of the movable deposits. This area is characterized by significant and extremely rapid sedimentary changes that influence the particle size distribution of the sediments. Overall, the sediment load capacity of coarse particles (fine coarse sand) is greater.

These results show that the physico-chemical properties of the sediments vary at the level of the vertical distribution and according to their spatial distribution. Successive floods have a direct effect on the dynamics of the physico-chemical properties of sediments along the Bandama River.

\section{Conflicts of Interest}

The authors declare no conflicts of interest regarding the publication of this paper.

\section{References}

AFNOR (Association Française de Normalisation) (1987). Qualité des sols: Méthodes d'analyse, Recueil de normes françaises (1ère éd., p. 136). Association Française de Normalisation.

Aubert, G. (1978). Méthodes d'analyses des sols (189 p). Centre National de Documentation Pédagogique.

Baize, D. (2000). Guide des analyses en pédologie (257 p). Institut national de la recherche agronomique.

Belin, S. (1992). Distribution microscopique de la matière organique disséminée dans les roches mères: Technique d'étude, interprétation des conditions de dépôt et de diagenèse (371 p). Thèse de doctorat de l'Université d'Orsay.

Billon, G. (2001). Géochimie des métaux et du soufre dans les sédiments des estuaires de la Seine et de l'Authie (168 p). Thèse, Université de Lille..

Bonnet, C. (2000). Développement de bio-essais sur sédiments et applications de l'étude, 
en laboratoire, de la toxicité de sédiments dulçaquicoles contaminés (326 p). Thèse de l'Université de Metz.

Bordovskiy, O. K. (1965). Accumulation and Transformation of Organic Substances in Marine Sediments. 2. Source of Organic Matter in Marine Basins. Marine Geology, 3, 5-31. https://doi.org/10.1016/0025-3227(65)90003-4

Boulvain, F. (2011a). Eléments de sédimentologie et de pétrologie sédimentaire. http://www2.ulg.ac.be/geolsed/sedim/sedimentologie.htm

Boulvain, F. (2011b). Une introduction aux processus sédimentaires. http://www2.ulg.ac.be/geolsed/processus/processus.htm

Boyer, C., Chaumont Chartier, D., \& Roy, A. G. (2010). Impact of Climate Change on the Hydrology of St. Lawrence Tributaries. Journal of Hydrology, 384, 65-83. https://doi.org/10.1016/j.jhydrol.2010.01.011

Brunet, R.-C., \& Astin, K. B. (2000). A 12-Month Sediment and Nutrient Budget in a Floodplain Reach of the River Adour, Southwest France. Regulated Rivers Research \& Management, 16, 267-277.

https://doi.org/10.1002/(SICI)1099-1646(200005/06)16:3\%3C267::AID-RRR584\%3E3.0 .CO;2-4

Cierjacks, A., Kleinschmit, B., Kowarik, L., Graf, M., \& Lang, F. (2010). Organic Matter Distribution in Floodplains Can Be Predicted Using Spatial and Vegetation Structure Data. River Research and Applications, 27, 1048-1057. https://doi.org/10.1002/rra.1409

Clinton, S. M., Power, M., \& Swenson, R. (2003). Impacts of Inundation Regime, Floodplain Vegetation, and Burrowing Animais on the Incorporation of Carbon into Floodplain Soils (pp. 1-9). CALFED Science Fellows Program, Project Number: R/SF-1.

Cyril, M. (2003). Origine et devenir de la matière organique des sédiments de mangroves de Guyane française: Précurseurs, Environnements de dépôt, Processus de décomposition et Relation avec les métaux lourds. Géologie appliquée (272p). Université d’Orléans.

Daniel, J., Dupont, J., \& Christian Jouannic, C. (1970). Etude de la relation entre le carbone organique et l'azote dans les sédiments de la Baie d'Ambaro (No. 16, p. 11). Office de la recherche scientifique et technique outre-mer.

Daniels, J. M. (2003). Floodplain Aggradation and Pedogenesis in a Semiarid Environment. Geomorphology, 56, 225-242. https://doi.org/10.1016/S0169-555X(03)00153-3

Delmas, D. (1980). Minéralisation de la matière organique et échanges ioniques à l'interface eau-sédiment de l'étang de Berre, Méditerranée. Oceanologica Acta, 3, 347-356.

Drouin, A., Saint-Laurent, D., Lavoie, L., \& Ouellet, C. (2011). High-Precision Digital Elevation Model to Evaluate the Spatial Distribution of Soil Organic Carbon Inactive Floodplains. Wetlands, 31, 1151-1164. https://doi.org/10.1007/s13157-011-0226-Z

Frazier, P., \& Page, K. A. (2008). Reach-Scale Remote Sensing Technique to Relate Wetland Inundation to River Flow. River Research and Applications, 25, 836-849. https://doi.org/10.1002/rra.1183

Gretener, B., \& Stromquist, L. (1987). Overbank Sedimentation Rates of Fine Grained Sediments. A Study of the Recent Deposition in the Lower River Fyrisan. Geografiska Annaler: Series A, Physical Geography, 69, 139-146. https://doi.org/10.1080/04353676.1987.11880202

Hartman, M., Muller, P. J., Suess, E., \& Van der Weidjen, C. H. (1976). Chemistry of Tate Quaternary Sediments and Their Interstitial Waters from the N-W African Continental Margin. "Meteor" Forschungsergeh, Reihe C, 24, 1-67.

Jindaluang, W., Kheoruenromne, L., Suddhiprakarn Bhupinder, P. S., \& Balwant, S. (2013). 
Influence of Soil Texture and Mineralogy on Organic Matter Content and Composition in Physically Separated Fractions Soils of Thailand. Geoderma, 195-196, 207-219. https://doi.org/10.1016/j.geoderma.2012.12.003

Kaplan, 1R., \& Rittenberg, S. C. (1963). Basin, Sedimentation and Diagenesis. In M. N. Hill (Ed.), The Sea (Vol. 3, pp. 583-619). Interscience Publish.

Keil, R. G., Montlucon, D. B., Prahl, F. R., \& Hedges, J. I. (1994). Sorptive Preservation of Labile Organic Matter in Marine Sediments. Nature, 370, 549-552. https://doi.org/10.1038/370549a0

Krull, E. S., Baldock, L. A., \& Skjemstad, J. O. (2003). Importance of Mechanisms and Processes of the Stabilization of Soil Organic Matter for Modelling Carbon Turnover. Functional Plant Biology, 30, 207-222. https://doi.org/10.1071/FP02085

Lavoie, L., Saint-Laurent, D., \& St-Laurent J. (2006). Analyse pédologique et sédimentologique des sols alluviaux et paléosols des terrasses d'inondation. Canadian Journal of Soil Science, 86, 813-826. https://doi.org/10.4141/S05-039

Leroy Poff, L. (2002). Ecological Response to and Management of Increased Flooding Caused by Climate Change. Philosophical Transactions of the Royal Society of London. Series A: Mathematical, Physical and Engineering Sciences, 360, 1497-1510. https://doi.org/10.1098/rsta.2002.1012

Mamadou, A. S. (2018). Hydrologie et géochimie des transports fluviaux dissous et particulaires dans le bassin versant du Milo (République de Guinée) (183 p). Thèse de doctorat, Université de Toulouse (INPT).

Meyers, P. A., \& Lallier-Vergès E. (1999). Lacustrine Sedimentary Organic Matter Records of Late Quaternary Paleoclimates. Journal of Paleolimnology, 21, 345-372. https://doi.org/10.1023/A:1008073732192

Monirul, M., Mirza, Q., Warrick, R. A., \& Ericksen, N. J. (2003). The Implications of C1imate Change on Floods on the Ganges, Brahmaputra and Meghna Rivers in Bangladesh. Climatic Change, 57, 287-318. https://doi.org/10.1023/A:1022825915791

Nadeu, E., De Vente, J., Martinez-Mena, M., \& Boix-Fayos, C. (2010). Exploring Particle Size Distribution and Organic Carbon Pools Mobilized by Different Erosion Processes at the Catchment Scale. Journal of Soils and Sediments, 11, 667-678. https://doi.org/10.1007/s11368-011-0348-1

Nestler, J. M., \& Long, K. S. (1997). Development of Hydrological Indices to Aid Cumulative Impact Analysis of Riverine Wetlands. Regulated Rivers: Research \& Management, 13, 317-334. https://doi.org/10.1002/(SICI)1099-1646(199707)13:4\%3C317::AID-RRR433\%3E3.0.C $\underline{\mathrm{O} ; 2-\mathrm{D}}$

Ouertani, N., Hamouda, R., \& Belayouni, H. (2006). Etude de la matière organique dans lessédiments superficiels d'un système aquatique confiné anoxique évoluant en milieu urbain: Cas du Lac sud de Tunis. Géo-Eco-Trop, 30, 1-34

Pfister, L., Kwaduijk, J., Musy, A., Bronstert, A., \& Hoffmann, L. (2004). Climate Change, Land Use Change and Runoff Prediction in the Rhine-Meuse Basins. River Research and Applications, 20, 229-241. https://doi.org/10.1002/rra.775

Rofes, G. (1980). Etude des sédiments. méthodes de prélèvemnt et d'analyses pratiquées au laboratoire de sédimentologie (50 p). Etude $\mathrm{N}^{\circ}$ 47, Ministère de l'Agriculture, GTGREF.

Saint-Laurent, D. (2007). Reconstruction of Flood Events and Links with Climatic Factors: A Case Study of the Saint-François Basin. JETS, 31, 5-24.

Saint-Laurent, D., \& Lavoie, L. (2009). Récurrence des inondations et édification des plaines alluviales des bassins du Centre-Sud du Québec (Canada). Revue des Sciences de l'Eau, 
22, 51-68. https://doi.org/10.7202/019823ar

Saint-Laurent, D., Hàhni, M., Baril, F., \& Chapados, C. (2011). Analysis of Hydrocarbon Contamination (C6C36 and ClOCSO) in Riparian Soils (Southern Québec, Canada). Proceedings of the International Conference of Environmental Pollution and Remediation (ICEPR) (pp. 17-19). International ASET Inc.

Schilling, K. E., Palmer, J. A., Bettis Iii, E. A., Jacobson, P., Schultz, R. C., Isenhart, T. M. (2009). Vertical Distribution of Total Carbon, Nitrogen and Phosphorus in Riparian Soils of Walnut Creek, Southern Iowa. Catena, 77, 266-273. https://doi.org/10.1016/j.catena.2009.02.006

Schipper, A. M., Lotterman, K., Leuven, R. S. E. W., Ragas, M. J., De Kroom, H., \& Hendricks, A. J. (2010). Plant Communities in Relation to Flooding and Soil Contamination in Lowland Rhine River Floodplain. Environmental Pollution, 159, 182-189. https://doi.org/10.1016/j.envpol.2010.09.006

Schneider, G. (2001). Boue de curage des cours d'eau. Le courrier de l'environnement de l'INRA. http://www.inra.fr/dpenv/curage.htm\#r41.

Shepard, F. (1954). Nomenclature Based on Sand-Silt-Clay Ratios. Journal of Sedimentary Petrology, 24, 151-158. https://doi.org/10.1306/D4269774-2B26-11D7-8648000102C1865D

Shields, F. D., Knight, S. S., \& Cooper, C. M. (2000). Cyclic Perturbation of Lowland River Channels and Ecological Response. Regulated Rivers: Research \& Management, 16, $307-$ 325.

https://doi.org/10.1002/1099-1646(200007/08)16:4\%3C307::AID-RRR582\%3E3.0.CO;2 $\underline{-2}$

Siegenthaler, U., \& Sarmiento, J. L. (1993). Atmospheric Carbon Dioxide and the Ocean. Nature, 365, 119-125. https://doi.org/10.1038/365119a0

Steiger, J., Gurnell, A. M., \& Goodson, J. M. (2003). Quantifying and Characterizing Contemporary Riparian Sedimentation. River Research and Applications, 19, 335-352. https://doi.org/10.1002/rra.708

Strom, L., Jans Son, R., Nils Son, C., Johansson, M. E., \& Xiong, S. (2011). Hydrologie Effects on Riparian Vegetation in a Boreal River: An Experiment Testing Climate Change Prediction. Global Change Biology, 17, 254-267.

https://doi.org/10.1111/j.1365-2486.2010.02230.x

Su, Z. Y., Xiong, Y. M., Zhu, J. Y., Ye, Y. C., \& Ye, M. (2006). Soil Organic Carbon Content and Distribution in a Small Landscape of Dongguan, South China. Pedosphere, 16, 10-17. https://doi.org/10.1016/S1002-0160(06)60020-9

Thurman, E. M., \& Malcolm, R. L. (1981). Preparative Isolation of Aquatic Humic Substances. Environmental Science \& Technology, 15, 463-466. https://doi.org/10.1021/es00086a012

Watkins, S. C., Quinn, G. P., \& Gawne, B. (2010). Changes in Inorganic-Matter Dynamics and Physic Chemistry, Associated with Riparian Vegetation Loss and River Regulation in Floodplain Wetlands of the Murray River, Australia. Marine and Fresh Water Research, 61, 1207-1217. https://doi.org/10.1071/MF09312

Woomer, P. L., Palm, C. A., Quresri, J. N., \& Kotto-Same, J. (1998). Carbon Sequestration and Organic Resource Management in African Smallholder Agriculture. In R. Lal, J. M. Kimble, R. F. Folett, \& B. A. Stewart (Eds.), Management of Carbon Sequestration in Soil (pp. 153-173). CRC Press Inc.

Zhang, L., \& Mitsch, W. J. (2006). Sediment Chemistry and Nutrient Influx in a Hydrologically Restored Bottomland Hardwood Forest in Midwestern USA. River Research 
and Applications, 23, 1026-1037. https://doi.org/10.1002/rra.1031

Zhou, Y. (2009). Evaluation de la biodisponibilité des métaux dans les sédiments (33 p). Rapport d'étude. Agence de l'Eau Artois-Picardie et Université des Sciences et Technologies de Lille I, UMR Géosystèmes. 